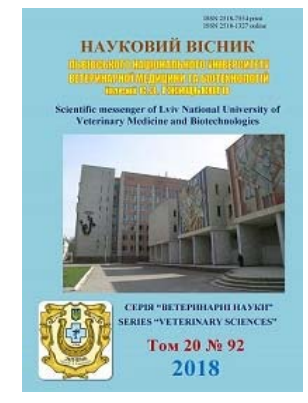

\author{
Науковий вісник Дьвівського національного університету \\ ветеринарної медицини та біотехнологій імені С.3. Гжицького
}

\author{
Scientific Messenger of Lviv National University \\ of Veterinary Medicine and Biotechnologies
}

UDC 619.615

\title{
Determination of acute toxicity of "Bendamin" drug in laboratory animals
}

\author{
I.S. Varkholiak, B.V. Gutyj
}

Stepan Gzhytskyi National University of Veterinary Medicine and Biotechnologies Lviv, Ukraine

Article info

Received 06.11.2018

Received in revised form 05.12 .2018

Accepted 06.12.2018

Stepan Gzhytskyi National University of Veterinary Medicine and Biotechnologies Lviv,

Pekarska Str., 50, Lviv, 79010, Ukraine.

Tel.: +38-096-486-26-85

E-mail:irynkavet@ukr.net
Varkholiak, I.S., \& Gutyj, B.V. (2018). Determination of acute toxicity of "Bendamin" drug in laboratory animals. Scientific Messenger of Lviv National University of Veterinary Medicine and Biotechnologies, 20(92), 209-212. doi: 10.32718/nvlvet9243

The study of acute toxicity is a mandatory stage in the investigation of new drugs, which allows assessing the health of substances for health in the short-term and determining the class of toxicity and breadth of therapeutic action. Therefore, at the first stage of the study, the acute toxicity of Bendamin Cardiomatography was studied, in particular the determination of maximum tolerant, toxic and intermittent lethal doses for laboratory animals. The acute toxicity of Bendamin was determined in two stages: indicative and expanded experiments. In the indicative trial, the drug was administered intragastrically at doses of 50, 500 and $5000 \mathrm{mg} / \mathrm{kg}$ body weight. Three white mice and rats were used for each dose. In an expanded experiment, Bendamin was administered intragastrically at doses of 5000 and $10000 \mathrm{mg} / \mathrm{kg}$ body weight. In determining the acute toxicity of Bendamin, the $D L_{50}$ value could not be determined, indicating a low toxicity of the test substance. Thus, the $D L_{50}$ drug for intragastric administration to white mice is greater than $5000 \mathrm{mg} / \mathrm{kg} \mathrm{m}$. The general condition of animals in the studied groups did not differ from the state of intact animals: coordination of movements and skeletal muscle tone, pain response, tactile and acoustic stimuli were adequate, the frequency of breathing and the rhythm of heart rate were within the normal range. At administration of the preparation in a dose of $5000 \mathrm{mg} / \mathrm{kg} \mathrm{m}$. T, an insignificant inhibition was established, which is related to the introduction of a large amount of the drug. In determining the coefficients of the mass of the internal organs of laboratory animals, a slight decrease in the weight coefficient of the liver was found in both mice and in rats. The "Bendamin" drug when administered to white mice and rats in the stomach in the maximum amount does not cause symptoms of poisoning and behavioral abnormalities. According to GOST 12.1.007-76, Bendamin, for intragastric administration, according to the degree of hazard belongs to grade 4 toxicity - low toxicity substances (DL 50 more than $10000 \mathrm{mg} / \mathrm{kg}$ body weight). In the future, it is planned to investigate the chronic toxicity and cumulative properties of the drug in laboratory animals.

Key words: pharmacology, toxicology, Bendamin preparation, mice, rats, acute toxicity.

\section{Визначення гострої токсичності препарату “Бендамін” на лабораторних тваринах}

\author{
І.С. Вархоляк, Б.В. Гутий \\ Львівський національний університет ветеринарної медицини та біотехнологій імені С.3. Гжицького, \\ м. Львів, Украӥна
}

Вивчення гострої токсичності є обов'язковим етапом дослідження нових лікарських засобів. Це дозволяє оцінити небезпечність речовин для здоров'я за умов короткотривалої дї та визначити клас токсичності й широту терапевтичної дії. Саме тому на першому етапі дослідження було вивчено гостру токсичність кардіопрепарату “Бендамін”, зокрема визначення максимально толерантних, токсичних і середньо-смертельних доз для лабораторних тварин. Гостру токсичність препарату “Бендамін” визначали у два етапи: орієнтовному та розгорнутому дослідах. В орієнтовному досліді вищезгаданий препарат вводили внутрішньошлунково в дозах 50, 500 і 5000 мг/кг маси тіла. На кожну дозу використовували по три білих миші та щури. У розгорнутому досліді Бендамін вводили внутрішньошлунково у дозах 5000 та 10000 мг/кг маси тіла. При визначенні гострої токсичності препарату “Бендамін” встановити величину DL50 не вдалося, щзо вказує про низьку токсичність досліджуваного засобу. Отже, DL 50 
препарату за внутрішньошлункового введення білим мишам є більшою за 5000 мг/кг м. т. Загальний стан тварин досліджуваних груп не відрізнявся від стану інтактних тварин: зберігалася координація рухів та тонус скелетних м'язів, реакції на больові, тактильні та звукові подразники були адекватними, частота дихання та ритм сериевих скорочень знаходилися в межах фізіологічних величин. Після введення препарату у дозі 5000 мг/кг м. т. встановлено незначне пригнічення, щзо, правдоподібно, пов'язано з введенням великої кількості препарату. За визначення коефічієнтів маси внутрішніх органів лабораторних тварин, встановлено незначне зменшення вагового коефіцієнта печінки як у мишей, так і у щурів. Препарат “Бендамін” при введенні в шлунок білим мишам та цурам у максимально допустимій кількості не викликає клінічних ознак отруєння та відхилень у поведінці. Згідно з ГОСТ 12.1.007-76, Бендамін, за внутрішньошлункового введення, за ступенем небезпечності відноситься до 4 класу токсичності малотоксичні речовини (DL50 більше 10000 мг/кг маси тіла). У подальшому планується дослідити хронічну токсичність та кумулятивні властивості препарату на лабораторних тваринах.

Ключові слова: фармакологія, токсикологія, препарат «Бендамін», миші, иури, гостра токсичність.

\section{Вступ}

Патології серця і судин у собак та кішок надзвичайно різноманітні та достатньо поширені у щоденній практиці лікаря ветеринарної медицини в Україні та за їі межами. Згідно класифікації професора Г.В. Домрачева, у домашніх тварин серцево-судинна патологія поділяється на хвороби міокарда, перикарда, ендокарда та хвороби кровоносних судин. Існує тісна залежність між вище вказаними патологіями, віком та породами тварин (Stekol'nikov, 2009; Undhad et al., 2012; Zhulikova, 2016).

За останні роки було проведено кілька значних досліджень в області лікування тварин з серцевою недостатністю. Крім того були введені нові методи діагностики, виявлено генетичні особливості окремих патологій. До того ж з'явилися нові лікарські засоби, наприклад: пімобендан, поліненасичені жирні кислоти, силденафіл, левосимендан, торасемід, небіволол, ізиноприл, клопідогрель та деякі інші для лікування тварин 3 патологією серцево-судинної системи (Varkholiak, 2016). Досі, даних про застосування нових терапевтичних засобів за лікування тварин $з$ патологією серцево-судинної системи недостатньо.

Отже, обгрунтовано виникає нагальна потреба 3 лікування тварин 3 патологією серцево-судинної системи. Крім того проведення всебічних досліджень механізмів дії згаданого вище лікарського засобу, його взаємодії із іншими аналогічними препаратами, клінічної ефективності лікування тварин та безпеки їх застосування.

Зважаючи на аналіз даних вітчизняних і зарубіжних дослідників розробка зручного у застосуванні і безпечного комплексного кардіологічного препарату, використання якого дозволить підвищити ефективність лікування тварин і широкого спектру серцевосудинних патологій $є$ на часі і становить актуальність проведення досліджень для ветеринарної медицини.

Метою роботи було вивчити гостру токсичність препарату “Бендамін” на лабораторних тваринах.

\section{Матеріал і методи досліджень}

Експериментальні дослідження проведені у відповідності до вимог лікарсько-біологічного експерименту 3 підбору аналогів, постановці контролю, дотриманню однакових умов годівлі та утримання під час проведення досліду та обліку результатів.
Гостру токсичність препарату “Бендамін” визначали у два етапи: орієнтовному та розгорнутому дослідах. В орієнтовному досліді препарат вводили внутрішньошлунково в дозах 50, 500 і 5000 мг/кг маси тіла. На кожну дозу використовували по три білих миші та щури. У розгорнутому досліді Бендамін вводили внутрішньошлунково у дозах 5000 та 10000 мг/кг маси тіла. Тваринам контрольних груп вводили ізотонічний розчин натрію хлориду. Після введення дослідного препарату спостереження за лабораторними тваринами здійснювали протягом 14 діб. У першу добу досліду тварини знаходились під постійним наглядом. За цих умов враховували такі показники: загальний стан, зовнішній вигляд, особливості поведінки тварин, інтенсивність та характер рухливої активності, наявність судом, координацію рухів, реакцію на зовнішні подразники (тактильні, звукові, світлові), стан волосяного покриву, видимих слизових оболонок, відношення до корму, ритм, частоту дихання, час виникнення та характер інтоксикації, іiі важкість, перебіг, час загибелі тварин або їх одужання (Kotsiumbas et al., 2006; Gutyj et al., 2017; Todoriuk et al., 2018; Gutyj et al., 2018).

\section{Результати та їх обговорення}

Гостру токсичність препарату “Бендамін” вивчали на щурах та мишах за одного шляху введення - внутрішньошлунковому, що передбачається для застосування у практиці ветеринарної медицини. При виборі дози під час вивчення гострої токсичності за умов внутрішньошлункового введення лімітуючим стало введення максимальної дози IV класу токсичності 5000 мг/кг.

За умов внутрішньошлункового введення кардіопрепарату "Бендамін” загибелі білих щурів не виявлено (табл. 1).

Після внутрішньошлункового введення препарату у вище вказаних дозах клінічних ознак інтоксикації у щурів не спостерігали тварини були охайними, активними, мали задовільний апетит, процеси сечовиділення і дефекації були в нормі, реагували на звукові та світлові подразники, порушення дихання та судом не відзначали. Рефлекторна збудливість у всіх тварин була збережена. Лише встановлено короткочасне пригнічення лабораторних тварин, яким задавали препарат у дозі 5000 мг/кг, що пов'язано з введенням в організм тварин великої кількості препарату. 
Таблиця 1

Показники токсичності препарату “Бендамін” на білих щурах

\begin{tabular}{|c|c|c|c|c|}
\hline \multirow{2}{*}{ Кількість тварин у групі } & \multirow{2}{*}{ Доза препарату, мг/кг } & \multicolumn{3}{|c|}{ Число загиблих тварин } \\
\hline & & всього & $\mathrm{y} \%$ & середній час загибелі \\
\hline 3 & 50 & 0 & 0 & 0 \\
\hline 3 & 500 & 0 & 0 & 0 \\
\hline 3 & 5000 & 0 & 0 & 0 \\
\hline 12 (двічі по 6 тварин) & 5000 & 0 & 0 & 0 \\
\hline
\end{tabular}

На наступну добу змін у клінічному стані тварин дослідних груп не спостерігали. Такі ж результати було отримано і за повторного введення лабораторним тваринам препарату у дозі 5000 мг/кг.

Отже, DL50 препарату за внутрішньошлункового введення білим щурам $є$ більшою за 5000 мг/кг м. т.
Результати $з$ визначення гострої токсичності препарату "Бендамін" за внутрішньошлункового введення білим мишам наведені у таблиці 2. Загибелі білих мишей за внутрішлункового введення препарату “Бендамін" у відповідних дозах не спостерігали. Явищ вираженої інтоксикації у тварин у ході експерименту не було встановлено.

Таблиця 2

Показники токсичності препарату “Бендамін” на білих мишах

\begin{tabular}{ccccc}
\hline \multirow{2}{*}{ Кількість тварин у групі } & \multirow{2}{*}{ Доза препарату, мг/кг } & \multicolumn{3}{c}{ Число загиблих тварин } \\
\cline { 3 - 5 } & 50 & 0 & 0 & всього \\
3 & 500 & 0 & 0 & 0 \\
3 & 5000 & 0 & 0 & 0 \\
12 (двічі по 6 тварин) & 5000 & 0 & 0 & 0 \\
\hline
\end{tabular}

Загальний стан тварин досліджуваних груп не відрізнявся від стану інтактних тварин: зберігалася координація рухів та тонус скелетних м'язів, реакції на больові, тактильні та звукові подразники були адекватними, частота дихання та ритм серцевих скорочень знаходилися в межах норми. Після введення препарату у дозі 5000 мг/кг м. т. встановлено незначне пригнічення, що пов’язано з введенням великої кількості препарату.

За визначення гострої токсичності препарату “Бендамін" визначити величину $\mathrm{DL}_{50}$ не вдалося, що вказує про низьку токсичність досліджуваного лікарського препарату.

Таблиця 3

Вплив препарату “Бендамін” на масу тіла дослідних тварин $(\mathrm{M} \pm \mathrm{m}, \mathrm{n}=6)$

\begin{tabular}{llrrr}
\hline \multirow{2}{*}{ Групи тварин } & Вид тварин & 3 доба & Маса тіла, г & доба \\
\cline { 3 - 5 } & & $19,1 \pm 0,50$ & $20,2 \pm 0,35$ & $20,6 \pm 0,41$ \\
\hline \multirow{2}{*}{ I (контрольна) } & миші & $168,1 \pm 2,62$ & $175,3 \pm 1,41$ & $185,6 \pm 0,96$ \\
& щури & $19,0 \pm 0,41$ & $20,3 \pm 0,24$ & $20,5 \pm 0,44$ \\
II (дослідна) & миші & $171,5 \pm 2,50$ & $176,3 \pm 2,11$ & $186,6 \pm 1,72$ \\
\hline
\end{tabular}

Встановлено, що маса тіла мишей та щурів контрольної групи на 14 добу досліду зростала порівняно 3 попередніми добами досліджень і відповідно становила $20,6 \pm 0,41$ і $185,6 \pm 0,96$ г, тоді як маса мишей i щурів дослідної групи - 20,5 \pm 0,44 і 186,6 \pm 1,72 г.
Отже, DL $_{50}$ препарату за внутрішньошлункового введення білим мишам є більшою за 5000 мг/кг м. т.

Саме тому, у розгорнутому досліді "Бендамін" вводили у дозі 5000 мг/кг маси тіла, використовуючи по 6 білих мишей та щурів. Як показали проведені дослідження (табл. 3), після одноразового внутрішньошлункового введення препарату "Бендамін” в дозі 5000 мг/кг маси тіла загибелі мишей та щурів не виявили. Встановлено, що препарат “Бендамін” у вказаній дозі не впливав на масу тіла тварин та вагові коефіцієнти маси внутрішніх органів (табл. 3,4$)$. 
Таблиця 4

Коефіцієнти маси внутрішніх органів лабораторних тварин $(\mathrm{M} \pm \mathrm{m}, \mathrm{n}=6)$

\begin{tabular}{|c|c|c|c|c|c|c|c|}
\hline \multirow{3}{*}{ Групи тварин } & \multirow{3}{*}{ Вид тварин } & \multicolumn{6}{|c|}{ Масові коефіцієнти внутрішніх органів } \\
\hline & & \multirow{2}{*}{ печінка } & \multirow{2}{*}{ селезінка } & \multirow{2}{*}{ серце } & \multirow{2}{*}{ тимус } & \multicolumn{2}{|c|}{ Нирки } \\
\hline & & & & & & права & ліва \\
\hline \multirow{2}{*}{ I (контрольна) } & миші & $51,4 \pm 0,3$ & $9,8 \pm 0,2$ & $5,4 \pm 0,1$ & $5,1 \pm 0,1$ & $9,0 \pm 0,2$ & $9,9 \pm 0,2$ \\
\hline & щури & $35,6 \pm 1,1$ & $4,1 \pm 0,1$ & $3,5 \pm 0,1$ & $2,5 \pm 0,2$ & $3,1 \pm 0,1$ & $3,3 \pm 0,2$ \\
\hline \multirow{2}{*}{ II (дослідна) } & миші & $49,8 \pm 0,5$ & $9,6 \pm 0,1$ & $5,6 \pm 0,2$ & $5,0 \pm 0,2$ & $8,7 \pm 0,3$ & $9,6 \pm 0,3$ \\
\hline & щури & $34,2 \pm 0,6$ & $4,0 \pm 0,1$ & $3,4 \pm 0,1$ & $2,4 \pm 0,2$ & $3,3 \pm 0,1$ & $3,4 \pm 0,1$ \\
\hline
\end{tabular}

Отже, новостворений препарат "Бендамін" належить до малотоксичних речовин 4 класу токсичності за ГОСТ 12.1.007-76.

\section{Висновки}

Препарат “Бендамін” після введення в шлунок білим мишам та щурам у максимально допустимій кількості не викликає клінічних ознак отруєння та відхилень у поведінці.

Згідно з ГОСТ 12.1.007-76, Бендамін, за внутрішньошлункового введення, за ступенем небезпечності відноситься до 4 класу токсичності - малотоксичні речовини (DL 50 більше 10000 мг/кг маси тіла).

У подальшому планується дослідити хронічну токсичність, кумулятивні властивості препарату на лабораторних тваринах.

\section{References}

Stekol'nikov, A.A. (2009). Bolezni sobak i koshek. Kompleksnaja diagnostika i terapija. SPb (in Russian). Undhad, V.V., Fefar, D.T., Jivan, B.M. Gupta, H., Ghodasara, D.J., Joshi, B.P., \& Prajapati, K.S. (2012). Cardiac troponin: an emerging cardiac biomarker in animal health. Vet. World, 5(8), 508-511. doi: $10.5455 /$ vetworld.2012.508-511.

Zhulikova, O.A. (2016). Monitoring rasprostranenija serdechno-sosudistyh zabolevanij sredi koshek i sobak v g. Blagoveshhensk amurskoj oblasti. Dal'- nevostochnyj agrarnyj vestnik, 2(38), 49-56. https://cyberleninka.ru/article/n/monitoringrasprostraneniya-serdechno-sosudistyh-zabolevaniysredi-koshek-i-sobak-v-g-blagoveschensk-amurskoyoblasti (in Russian).

Varkholiak, I.S. (2016). The usage of medicines at the cardiovascular pathologies in dogs and cats. Scientific Messenger LNUVMBT named after S.Z. Gzhytskyj, 18, 3(71), 261-265. https://nvlvet.com.ua/index.php/ journal/article/view/974.

Kotsiumbas, I.Ia., Malyk, O.H., \& Patereha, I.P. (2006). Doklinichni doslidzhennia veterynarnykh likarskykh zasobiv. L.: Triada plius (in Ukrainian).

Gutyj, B., Khariv, I., Binkevych, V., Binkevych, O., Levkivska, N., Levkivskyj, D., \& Vavrysevich, Y. (2017). Research on acute and chronic toxity of the experimental drug Amprolinsyl. Regul. Mech. Biosyst., 8(1), 41-45. doi: 10.15421/021708.

Gutyj, B., Grymak, Y., Hunchak, V., Mysak, A., Nazaruk, N., Brezvyn, O., Hariv, I., Shcherbatyy, A., Semeniv, B., Bushueva, I., Parchenko, V., \& Kaplaushenko, A. (2018). Preclinical searches of the preparation Thireomagnile. Ukrainian Journal of Ecology, 8(1), 688-695. doi: 10.15421/2018 267.

Todoriuk, V.B., Hunchak, V.M., Gutyj, B.V., Gufriy, D.F., Hariv, I.I., Khomyk, R.I. , \& Vasiv, R.O. (2018). Preclinical research of the experimental preparation "Ferosel T". Ukrainian Journal of Veterinary and Agricultural Sciences, 1(1), 3-9. doi: 10.32718/ujvas1-1.01. 